\title{
Meneguhkan Nilai Keindonesiaan melalui Program Deradikalisasi Anak Usia Dini di Kampung Karanggading Kota Magelang
}

\author{
Joko Tri Nugraha", Retno Dewi Pramodia Ahsani, Nike Mutiara Fauziah \\ Jurusan Ilmu Administrasi Negara, FISIP, Universitas Tidar, Kota Magelang, Indonesia \\ *Corresponding Author \\ Jl. Kapten Suparman No.39, Tuguran, Potrobangsan, Kec. Magelang Utara, \\ Kota Magelang, Jawa Tengah 56116 \\ E-mail: jokotri.nugraha@untidar.ac.id \\ Received: Revised: Accepted: Published: \\ 30 October 201924 April $2020 \quad 21$ May $2020 \quad 31$ Mei 2020
}

\begin{abstract}
Abstrak
Kegiatan Pengabdian Kepada Masyarakat ini dilatarbelakangi oleh keterlibatan kaum muda dan terlebih anak-anak dalam pusaran ideologi radikalisme. Anak muda yang menganut ideologi radikalisme merupakan isu yang harus dicermati di tengah bonus demografi yang tengah berlangsung di negeri ini tidak terkecuali pada salah satu daerah di Kota Magelang yaitu di Kampung Karanggading. Adapun tujuan dari pengabdian masyarakat ini adalah untuk meneguhkan nilai keindonesiaan melalui kegiatan bermain sambil belajar dan kegiatan cinta lingkungan sebagai upaya meningkatkan rasa cinta tanah air, budaya, keagamaan dan lingkungan. Metode yang digunakan dalam pengabdian ini diantaranya dengan beberapa tahapan program dongeng nusantara bagi anak, program outbond, belajar dan bermain bagi anak dan program bersih lingkungan bagi anak. Hasil kegiatan pengabidan kepada masyarakat ini diantaranya kegiatan dongeng nusantara, outbond dan kerjabakti menumbuhkan budaya anti kekerasan dan radikalisme dan masyarakat Kampung Karanggading, khususnya anak-anak mendapatkan pemahaman nilai-nilai nasionalisme dalam kehidupan mereka sehari-hari.
\end{abstract}

Kata kunci: nasionalisme; deradikalisai; anak usia dini.

\begin{abstract}
This Community Service Activity is motivated by the involvement of young people and especially children in the impact of radical ideology. Young people who adhere to the ideology of radicalism are an issue that must be observed in the midst of the demographic bonus that is taking place in this country, not least in one area in the Magelang City, in Kampung Karanggading. The purpose of this community service is to strengthen the value of Indonesianism through play activities while learning and loving activities in an effort to increase the patriotism, culture, religion and environment. The methods used several stages of the Indonesian fairytale program for children, outbound programs, learning and playing for children and a clean environment program for children. The results of community service activities include the folklore activities of the archipelago, outbound and collaborative work fostering a culture of anti-violence and radicalism and the people of Kampung
\end{abstract}

80 || Indonesian Journal of Community Services 
Karanggading, especially children get an understanding of the values of nationalism in their daily lives.

Keywords: nationalism; deradicalization; early childhood.

\section{PENDAHULUAN}

Gerakan radikalisme dan terorisme masih tetap menjadi salah satu ancaman nasional terpenting di negeri ini yang dinilai lebih sulit dideteksi (Jafar et al., 2019). Pandangan bahwa ideologi dan gerakan radikal menjadi ancaman terpenting bukanlah hal yang berlebihan, mengingat rentetan aksi terorisme yang terjadi pada tataran internasional, regional dan nasional tetap menunjukkan trend yang mengkhawatirkan. Dalam konteks Indonesia, ideologi radikal yang nyata-nyata bertentangan dengan Pancasila justru mengalami perkembangan dan penerimaan dari kelompok-kelompok warga negara Indonesia. Ideologi-ideologi dan gerakan radikal tersebut jelas telah mampu menggerakkan aktor-aktor dari warga sipil menjadi pelaku teror (Hikam, 2016). Warga sipil yang seharusnya merupakan salah satu komponen pendukung pertahanan dan keamanan nasional justru berbalik menjadi para penyebar ideologi radikal dan pelaku aksiaksi teror yang mengancam keamanan nasional secara masif. Bahkan, kondisi keterbukaan sebagai hasil dari demokratisasi kini telah dimanfaatkan oleh para pendukung radikalisme tersebut sehingga memberikan ruang gerak yang lebih besar bagi mereka untuk berkiprah. Kondisi ini jelas perlu ditanggulangi, dan salah satu strategi yang perlu dikembangkan adalah melalui pendekatan lunak (Soft Power) seperti program deradikalisasi yang turut melibatkan masyarakat sipil Indonesia (Royani, 2013).

Berbagai penelitian terdahulu yang relevan sudah dilakukan diantaranya penelitian yang dilakukan oleh Yudi Latif (2018) tentang Identitas Keindonesiaan dan Aktualisasi Pancasila bagi Generasi Milenial di Era Digital, hasil penelitian menunjukan Kaum muda dan pergerakan menjadi pembentuk kebangsaan Indonesia. Titik-titik pertumbuhan (milestone) kebangsaan Indonesia ini jelas didukung oleh "kemudaan" yaitu suatu ciri akan optimisme baru dan keyakinan akan perjuangan meski situasi kemasyarakatan tidak langsung menjadi bukti perjuangan mereka (not self-evident). Selain penelitian tentang identitas keindonesiaan, terdapat penelitian terdahulu yang relevan tentang Relevansi dan Aplikasi Doktrin Wawasan Nusantara dalam Analisis Ancaman Kontemporer Haryo B. Rahmadi (2018) seorang Pakar Tetap Dewan Ketahanan Nasional dengan hasil penelitian yang menunjukan bahwa terbukti bahwa Wawasan Nusantara sebagai doktrin strategis geopolitik nasional tidak saja relevan secara ilmiah, namun juga terbukti komprehensif. Selain itu penelitian tentang Pencegahan Radikalisme Melalui Penanaman Nilai-Nilai Multikultural oleh Amar Salahuddin Novel Indonesia (2015) yang menunjukan bahwa di dalam novel-novel Indonesia ditemukan nilai-nilai multikultural, yaitu nilai belajar hidup dalam perbedaan (toleransi), nilai membangun saling percaya, nilai memelihara sikap saling menghargai, nilai terbuka dalam berpikir, serta nilai apresiasi dan interdependen. Dengan penanaman nilai-nilai multikultural dalam dunia pendidikan dan menanamkan kecerdasan berbudaya inilah merupakan salah satu penanggulangan dan pencegahan radikalisme.

Penelitian tentang Pencegahan Gerakan Radikalisme melalui Penanaman Ideologi Pancasila dan Budaya Sadar Konstitusi Berbasis Komunitas oleh Satriawan et al (2019) menunjukan Persoalan komunitas masyarakat saat ini adalah adanya gerakan-gerakan radikalisme yang memiliki agenda terselubung yang menggerogoti nilai-nilai Pancasila memecah belah bangsa Indonesia, melemahkan persatuan dan kesatuan - merusak kebhinekaan yang sejak Indonesia berdiri telah menjadi konsensus bersama. Selain itu penelitian lain yang relevanpenelitian tentang Merawat Kebhinekaan Menjaga Keindonesiaan: Belajar dari Nilai Keberagaman dan Kebersatuan Masyarakat Pulau oleh Susilowati \& Masruroh (2018) yang 
menunjukan bahwa Penduduk Natuna dan Karimunjawa yang memiliki keberagaman dalam etnik, agama, dan budaya ternyata tetap mampu merawat kebhinekaan dan menjaga keindonesiaan, sehingga bisa menjadi contoh bagi warga bangsa lain, terutama yang berada di dekat pusat pemerintahan dengan berbagai fasilitas, tetapi justru kurang mampu merawat dan menjaga kebhinekaan. Penelitian tentang Pendidikan Karakter dalam Upaya Menangkal Radikalisme di Sma Negeri 3 Kota Depok, Jawa Barat oleh Saihu dan Marsiti (2019) menunjukan bahwa Pendidikan karakter dalam upaya menangkal radikalisme di SMA Negeri 3 Kota Depok Jawa Barat menggunakan implementasi pendidikan karakter yang diintegrasikan pada kurikulum formal dan hidden curriculum.

Berdasarkan beberapa penelitian terdahulu yag relevan tersebut penulis tertarik untuk melakukan pengabdian masyarakat dengan tema Meneguhkan Nilai Keindonesiaan Melalui Program Deradikalisasi namun perbedaannya adalah lebih difokuskan pada sasaran program yaitu anak-anak karena berbagai rasionalisasi, diantaranya keterlibatan kaum muda dan terlebih anak-anak, dalam pusaran ideologi radikalisme dan terorisme keagamaan merupakan fakta yang tidak terbantahkan. Selalu ada kelompok anak muda yang aktif terlibat dalam setiap peristiwa kekerasan atau terorisme keagamaan, baik di tanah air maupun di belahan dunia lain (Dan Efriza, 2017). Dari hal tersebut, diperlukan sebuah kebijakan dan program deradikalisasi yang secara spesifik menempatkan anak-anak khususnya remaja sebagai target utama, bukan lagi kebijakan biasa yang berlaku umum. Di Indonesia, sejumlah peristiwa radikalisme dan terorisme selalu melibatkan anak remaja. Sekalipun bukan sebagai kapasitas ideolog atau mentor spiritual, para pelaku aktif selalu didominasi anak remaja. Beberapa nama dibalik serangkaian peristiwa terorisme yang terjadi di Surabaya dan Sidoarjo, semuanya digerakkan dan dilakukan oleh satu keluarga, termasuk anak-anak.

Keterlibatan kaum muda dibalik fenomena gerakan ISIS lebih mencengangkan lagi. Sebagaimana yang bisa kita saksikan, kejadian tiga gereja yang menjadi sasaran aksi terorisme yaitu, Gereja Santa Maria Tak Bercela Ngagel Madya, Gereja Kristen Indonesia Jalan Diponegoro dan Gereja Pantekosta Pusat Surabaya Jalan Arjuna dengan selang 30 menit bom meledak dan kemudian terjadi lagi pada pukul 08.50 WIB di Polrestabes Surabaya (13 Mei 2018). Serangan bom di beberapa tempat tersebut setelah dicermati terdapat anak-anak di bawah usia 10 tahun ke bawah yang menjadi pelaku kekerasan dan bom bunuh diri. Artinya anak-anak telah menjadi korban radikalisasi ideologi keagamaan oleh para orang tua yang seharusnya menjadi penjaga ideologi bagi anak-anaknya. Banyaknya anak muda yang menganut ideologi radikalisme merupakan isu yang harus dicermati di tengah bonus demografi yang tengah berlangsung di negeri ini. Berdasarkan data dari Kementerian Perencanaan Pembangunan/Bappenas diperkirakan jumlah penduduk Indonesia pada tahun 2045 mencapai 321 juta jiwa. Adapun jumlah penduduk dengan usia produktif, diperkirakan mencapai 209 juta jiwa. Jika ledakan usia angkatan kerja produktif tidak dikelola secara baik, bonus demografi dapat menjadi musibah daripada berkah. Pada gilirannya, ledakan penduduk bisa menimbulkan berbagai bentuk patologi sosial seperti kemiskinan, pengangguran, kriminalitas, ketimpangan sosial dan semacamnya. Dalam kondisi seperti ini paham radikalisme sangat rawan menjangkiti remaja.

Dari hal tersebut, diperlukan sebuah kebijakan dan program deradikalisasi yang secara spesifik menempatkan anak-anak khususnya remaja sebagai target utama, bukan lagi kebijakan biasa yang berlaku umum. Deradikalisasi merupakan strategi yang didasari oleh suatu pemahaman konseptual untuk menangani masalah terkait perkembangan ideologi-ideologi dan 
aksi-aksi radikalisme. Pemerintah dan sektor masyarakat sipil Indonesia harus berupaya terus menerus untuk menghentikan, meniadakan atau paling tidak menetralisasi radikalisme (Asrori, 2017). Netralisasi ideologi pada hakikatnya tetap dibutuhkan sebagai upaya untuk memperkuat benteng pertahanan ideologis dari warga negara terutama anak-anak, sebagai penetrasi dan pengaruh ideologi radikal yang dibawa dan dipropagandakan oleh kelompok radikal.

Berdasarkan hasil observasi yang telah dilaksanakan oleh Tim Pengabdian Kepada Masyarakat, Kampung Karanggading merupakan salah satu kampung yang terdapat di Kota Magelang tepatnya di Kelurahan Rejowinangun Selatan, Kecamatan Magelang Selatan, Kota Magelang Jawa Tengah. Kampung Karanggading sendiri terdiri dari beberapa RW, yang per RW nya terdiri dari rata-rata 150 Kepala Keluarga. Beberapa persoalan yang mengemuka di Kampung Karanggading antara lain:

a. Segi sosial

Kehidupan sosial di Kampung Karanggading dapat dilihat dari hubungan atau interaksi sosial oleh dua orang atau lebih. Di Kampung Karanggading terdapat kurang lebih 50 anak yang duduk di bangku SD. Rata-rata anak ini berusia 7-13 tahun. Secara psikologi, usia-usia tersebut merupakan masa emas yang dimiliki oleh seorang anak untuk membangun hubungan sosial yang diharapkan yaitu ke arah yang lebih baik. Meski demikian perilaku anak-anak di Kampung Karanggading tidak berlaku dengan semestinya. Banyak anak yang mengucapkan kata-kata yang tidak lazim dan tidak seharusnya diucapkan kepada teman-temannya.

b. Budaya

Sisi budaya masyarakat Kampung Karanggading adalah soal cara berpakaian anak dan remaja. Anak-anak sekarang lebih menyukai cara berpakaian masa kini yang minim, dan tampaknya kebiasaan berpakaian ini mendapat dukungan penuh dari orang tuanya dengan alasan akan menampakkan kelucuannya. Padahal kebiasaan anak memakai baju yang minim mengajarkan sesuatu yang tidak baik, karena berpotensi menjadi korban tindak kejahatan seksual bagi orang-orang dewasa di lingkungan sekitar.

c. Keagamaan

Kehidupan keagamaan di Kampung Karanggading sudah berjalan baik, meski aktivitas keagamaan tidak banyak diikuti oleh anak-anak kecil. Hanya sebagian kecil anak-anak yang mengikuti kegiatan keagamaan, hal ini dikarenakan orang tua kesehariannya bekerja serabutan sehingga kurang bisa mengontrol putra-putri mereka.

d. Mutu layanan atau kehidupan bermasyarakat

Lingkungan Kampung Karanggading terkenal dengan padat penduduknya sehingga rumah-rumah di Kampung Karanggading saling berdimpitan satu sama lainnya. Lingkungan di Kampung Karanggading juga terkenal sebagai lingkungan yang berada di zona garis bahaya, artinya banyak berita-berita negatif yang sudah tersebar di media massa tentang Kampung Karanggading.

Berdasarkan indikasi masalah tersebut makan solusi yang diajukan dari pelaksanaan pengabdian kemitraan masyarakat di Kampung Karanggading ini, antara lain:

a. Segi sosial

Di Kampung Karanggading terdapat kurang lebih 50 anak yang duduk di bangku SD.

Rata-rata anak ini berusia 7-13 tahun. Secara psikologi, usia-usia tersebut merupakan masa emas yang dimiliki oleh seorang anak untuk membangun hubungan sosial yang diharapkan yaitu ke arah yang lebih baik. Lingkungan Kampung Karanggading juga terkenal dengan orang-orangnya yang brutal, banyak kasus tawuran yang berhubungan dengan Kampung Karanggading. Banyak anak usia SD yang suka berkelahi. Pada aspek 
sosial tim akan melakukan kegiatan pendidikan kewarganegaraan melalui bermain dan belajar. Metode ini merupakan kombinasi untuk meningkatkan rasa cinta tanah air, seperti dongeng nusantara, outbond bersama.

b. Budaya

Sisi budaya masyarakat Kampung Karanggading adalah soal cara berpakaian anak dan remaja. Anak-anak sekarang lebih menyukai cara berpakaian masa kini yang minim, dan tampaknya kebiasaan berpakaian ini mendapat dukungan penuh dari orang tuanya dengan alasan akan menampakkan kelucuannya. Pada aspek budaya, tim akan mengenalkan pakaian adat dari berbagai daerah di nusantara melalui dongeng nusantara, permainan dan mewarnai pakaian adat.

c. Keagamaan

Kehidupan keagamaan di Kampung Karanggading sudah berjalan baik, meski aktivitas keagamaan tidak banyak diikuti oleh anak-anak kecil. Pada aspek keagamaan ini tim akan bekerjasama dengan karang taruna untuk menghidupkan kembali kegiatan TPQ untuk anak-anak.

d. Mutu layanan atau kehidupan bermasyarakat Lingkungan Kampung Karanggading terkenal dengan padat penduduknya sehingga rumah-rumah di Kampung Karanggading saling berdimpitan satu sama lainnya. Pada aspek mutu kehidupan, tim akan melakukan kegiatan sosialisasai kebersihan lingkungan yang melibatkan anak dengan kerja bakti bersama.

Pengabdian masyarakat melalui pemberdayaan masyarakat yang dilakukan di Kampung Karanggading akan membantu masyarakat dalam memfasilitasi menciptakan lingkungan yang kondusif (Teguh, 2004). Melalui program deradikalisasi anak usia dini, di samping itu untuk membantu masyarakat mendesain pola partisipasi sebagai kader pembangunan. Sementara untuk kelayakan mitra, beberapa persoalan yang mengemuka berdasarkan hasil observasi antara lain dari aspek sosial, aspek budaya, keagaamaan dan mutu kehidupan. Pada aspek sosial jumlah anak di kampung Karanggading berusia antara 7-13 tahun. Kondisi ini menjadi alasan pentingnya dilakukan program deradikalisasi bagi anak usia dini. Dari aspek budaya, jenis pekerjaan tukang bangunan masih dominan banyak penduduk di Kampung Karanggading termasuk ke dalam ekonomi menengah ke bawah. Dari kondisi ini perlu dilakukan perubahan mindset penduduk agar dapat beralih profesi sehingga kesejahteraannya dapat meningkat dengan segala potensi yang ada di Kampung Karanggading. Mendasarkan beberapa persoalan seperti yang dipaparkan di atas, maka Kampung Karanggading sangat layak untuk dijadikan lokasi pengabdian kemitraan masyarakat (PKM). Tim pengusul menawarkan konsep program deradikalisasi bagi anak untuk meneguhkan nilai keindonesiaan (Arif, 2014).

\section{METODE}

Rancangan kegiatan pengabdian masyarakat kemitraan masyarakat (PKM) yang dilakukan oleh tim pengusul secara bertahap sesuai dengan tahapan pemberdayaan masyarakat menggali potensi lokal (Kiki, 2020), adapun tahap-tahap kegiatan tersebut seperti gambar di bawah ini: 


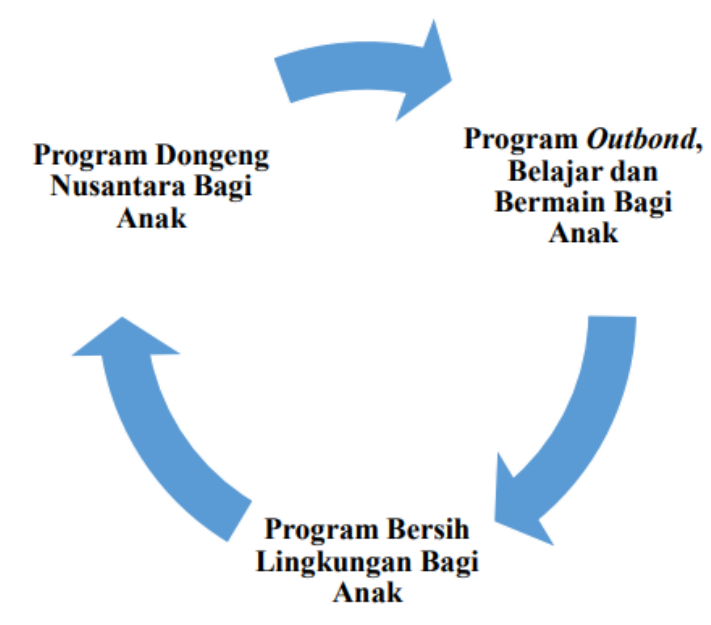

Gambar 1. Metode Pelaksanaan Program

Sumber: Sintesis Penulis, 2019

a. Tahapan pertama tim pengabdian melakukan observasi di Kampung Karanggading. Kemudian melakukan pemetaan potensi permasalahan yang dimiliki oleh Kampung Karanggading baik dari sisi sosial, budaya, kegamaan dan mutu kehidupan.

b. Tahapan kedua setelah tim mampu memetakan potensi yang dimiliki oleh Kampung Karanggading maka tahap berikutnya tim akan mengidentifikasi masalah dari sisi sosial, budaya, keagamaan dan mutu kehidupan. Program Outbond, Belajar dan Bermain Bagi Anak Program Bersih Lingkungan Bagi Anak Program Dongeng Nusantara Bagi Anak 8

c. Tahapan ketiga tim pengabdian akan melakukan diskusi di Balai Kelurahan Karanggading dengan mengundang 30 orang penduduk yang berasal dari kalangan wanita (sebagai kelompok PKK), kalangan pemuda (sebagai kelompok Karang Taruna) serta kelompok tokoh masyarakat desa.

d. Identifikasi masalah yang diperoleh di lapangan akan diusulkan dalam kegiatan musyawarah bersama aparat kelurahan, tokoh masyarakat serta perwakilan karang taruna.

e. Tahapan selanjutnya Tim Pengabdian melakukan fasilitasi pendampingan kegiatan yang sudah dimusyawarahkan dalam pertemuan bersama tokoh serta masyarakat di Kampung Karanggading.

Selain rancangan kegiatan, adapun metode yang digunakan dalam menentukan khalayak sasaran menggunakan metode purposive sampling dan snowball sampling (Sugiyono, 2010). Metode pengumpulan data yang digunakan dengan wawancara, observasi dan dokumentasi. Analisis data menggunakan pendekatan analisis tematik, yakni mengidentifikasi tema yang dituturkan oleh partisipan. Kemudian dilakukan reorganisasi cerita (restorying) menjadi beberapa jenis kerangka umum: mengumpulkan data, menganalisis data untuk menemukan unsur dalam cerita (waktu, tempat, alur, dan suasana), dan menuliskan kembali cerita tersebut untuk menempatkannya dalam sebuah rangkaian kronologis. 


\section{HASIL DAN PEMBAHASAN}

Dalam menghadapi gerakan radikal, pandangan dan ideologi radikal perlu dipahami karena hal tersebut menyangkut pemahaman dan dasar pemikiran. Persoalan ideologi dan di dalamnya termasuk nasionalisme, masih tetap menjadi salah satu bahasan terpenting dalam ilmu sosial dan kemanusiaan pada umumnya, dan ilmu politik pada khususnya. Perkembangan politik pada tataran global, regional dan nasional pada akhir abad ke-20 dan awal abad ke-21 ditengarai dengan kembalinya ideologi dalam wacana dan praktik politik. salah satunya adalah muncul dan berkembangnya berbagai gerakan politik yang memiliki skala global dan regional yang didasari pada ideologi-ideologi baru, termasuk nasionalisme religius (religious nationalism) dan nasionalisme etnis (ethnic nationalism).

Fenomena gerakan fundamentalisme, radikalisme dan aksi-aksi terorisme yang menggunakan ideologi berbasis ajaran agama-agama, bukan saja bersifat nasional, tetapi juga trans nasional (Maksum, 2017). Kajian tentang ideologi dan nasionalisme juga mengalami reviral di era globalisasi saat ini. Salah satu dampak terpenting dari proses globalisasi adalah semakin kaburnya batas-batas artifisial maupun imajiner dari negara-negara. Berkembangnya ekonomi pasar, pesatnya teknologi informasi dan transformasi serta terbukanya hubungan lintas negara pasca perang dingin berkontribusi besar dalam akselerasi globalisasi yang pada gilirannya ikut mengaburkan batas-batas yang selama ini dibuat dan dibayangkan wujudnya. Ironisnya, justru karena itulah kemudian muncul perlawanan dari berbagai sektor di dalam masyarakat yang kemudian membangkitkan kembali semangat primordialisme, lokalitas, multikulturalisme dan nasionalisme dalam berbagai bentuk dan ekspresinya.

Penanggulangan terorisme melalui pendekatan lunak memerlukan landasan idiil yang komprehensif. Pancasila diyakini sebagai salah satu pendekatan lunak yang selaras dengan perwujudan program deradikalisasi (Lusi, 2017). Selain itu, Pancasila turut berfungsi sebagai falsafah hidup berbangsa serta ideologi nasional, yang konsep dan visinya dapat dijabarkan ke dalam kehidupan masyarakat Indonesia. Pancasila diyakini mampu menyaring berbagai pengaruh ideologi yang masuk ke Indonesia sebagai konsekuensi logis dari sebuah masyarakat dan bangsa yang majemuk (bhineka). Bangsa Indonesia tidak menafikkan kehadiran budaya luar maupun ideologi luar, tetapi melalui Pancasila negara dapat memilah pengaruh mana yang dapat diterima atau tidak. Negara juga mampu menyesuaikan pengaruh luar tersebut dengan konteks budaya Indonesia ataupun menolak karena tidak sesuai dengan falsafah, cita-cita moral dan ideologi nasional.

Terdapat lima sila yang secara komprehensif menjabarkan arti kehidupan bernegara yang dapat dijadikan landasan melawan ancaman ideologi radikal diantaranya:

1. Sila Pertama, Ketuhanan Yang Maha Esa Sila ini mengandung makna tauhid, toleransi, kemajemukan dan moderat yang seimbang. Dalam konteks hubungan antarumat beragama, Pancasila menolak pemaksaan kehendak oleh pribadi maupun kelompok terhadap satu sama lain berdasarkan pada penafsiran agama yang dianggap paling benar. Ideologi fundamentalis radikal bertentangan dengan Pancasila karena ia memaksakan kehendak dengan menolak memberikan ruang kepada penafsiran yang berbeda. Pernyataan kebenaran yang absolut seperti itu akan merusak tatanan masyarakat, bangsa dan negara yang memiliki ciri pluralis.

2. Sila Kedua, Kemanusiaan yang Adil dan Beradab Sila ini mengandung makna pengakuan terhadap hak asasi manusia, termasuk hak sipil, politik, ekonomi dan hak sosial budaya. Dengan demikian, pemaksaan kehendak oleh kelompok radikal secara hakiki bertentangan dengan Pancasila karena jelas melanggar HAM yang menjadi landasan dalam kehidupan berbangsa dan bernegara. 
3. Sila Ketiga, Persatuan Indonesia Sila ini mengandung makna bahwa Indonesia adalah negara yang dibentuk berdasarkan asas kebangsaan, bukan atas dasar agama, suku atau ras tertentu. Kelompok fundamentalis radikal yang ingin mengganti asas kebangsaan dengan asas yang lain, berarti ingin mengubah dasar NKRI dari negara kebangsaan menjadi negara Islam. hal ini tentunya jelas bertentangan dengan landasan ideologi nasional Pancasila.

4. Sila Keempat, Kerakyatan yang Dipimpin oleh Hikmah Kebijaksanaan dalam Permusyawaratan Perwakilan Sila ini mengandung arti bahwa sistem kemasyarakatan dan kenegaraan di Indonesia harus berlandaskan pada prinsip demokrasi. Kedaulatan berada di tangan rakyat yang jelas bertentangan dengan sistem totaliter yang ingin didirikan oleh kelompok fundamentalis radikal. Pada umumnya ideologi agama radikal menolak kedaulatan rakyat dan hanya mengakui kedaulatan Tuhan yang dilaksanakan melalui sistem teokrasi.

5. Sila Kelima, Keadilan Sosial Bagi Seluruh Rakyat Indonesia Sila ini mengandung makna bahwa kesejahteraan menjadi hak warga negara RI.

Pemerintah sebagai penyelenggara negara mempunyai kewajiban untuk menciptakan kesejahteraan bagi warga negaranya. Hal ini berarti sistem totaliter yang eksploitatif bertentangan dengan Pancasila karena ia tidak mengakui adanya hak bagi warga negara untuk memperoleh kesejahteraan sebagai hak dasar mereka. Agenda pertama dalam kegiatan pengabdian kemitraan masyarakat adalah kegiatan mendongeng. Dongeng yang dilakukan adalah dongeng nusantara dengan mengadopsi cerita yang berisi edukasi untuk anak, seperti cerita malin kundang, ande-ande lumut dan cerita si kancil. Cerita yang berisi pembelajaran dan nasehat untuk anak kami tayangkan bergantian dan di setiap satu sesi penanyangan kami selingi dengan permainan dan hiburan serta pemberian doorprize bagi anak yang berhasil menjawab pertanyaan yang diajukan. Pada kegiatan dongeng nusantara ini, anak-anak di Kampung Karanggading diberikan pertanyaan ringan seperti contoh perbuatan sehari-hari mereka. Kemudian anak-anak diminta memperkenalkan diri mereka sekaligus menyebutkan cita-cita mereka setelah besar nanti.

Tahapan selanjutnya adalah kegiatan untuk membangkitkan rasa nasionalisme anak-anak di Kampung Karanggading. Salah satu karakter atau elemen utama dalam nasionalisme adalah identitas sebagai sebuah bangsa. Nasionalisme tidak sama dengan patriotisme, yang lebih merupakan suatu pengkondisian sosial dan perilaku individual untuk mendukung keputusan tindakan sebuah negara. Penguatan nasionalisme harus dilakukan kepada setiap elemen bangsa karena sebenarnya merekalah aktor-aktor yang diharapkan melawan ancaman radikalisme secara langsung dalam kehidupan sosial Indonesia. Program kegiatan kami yang kedua adalah outbond dan bermain bersama anak-anak di Kampung Karanggading. kegiatan kedua ini kami berusaha membangun kekompakan anak dan juga kekompakan tim pelaksana pengabdian. Pemberian doorprize bagi anak memotivasi mereka untuk belajar berani dan jujur, yang merupakan modal dasar bagi mereka dalam menjalani kehidupan kelak.

Selanjutnya kegiatan ketiga yang kami lakukan adalah kerja bakti bersama anak dan warga masyarakat di Kampung Karanggading. Pertumbuhan organisasi teroris dapat dipicu dari kebiasaan budaya (cultural habbit) yang menerima tindakan kekerasan atau radikalisme. Isu kultural yang dikaitkan dengan fenomena terorisme di Indonesia memperlihatkan mudahnya pengaruh ideologi radikal untuk masuk. Kegiatan gotong royong kerja bakti yang kami lakukan bermaksud untuk membiasakan warga hidup sehat dan salah satu upaya untuk mempererat persaudaran di antara mereka. 
Indonesian Journal of Community Services

Volume 2, No. 1, May 2020

http://jurnal.unissula.ac.id/index.php/ijocs

DOI: http://dx.doi.org/10.30659/ijocs.2.1.80-91

Agenda pertama dalam kegiatan pengabdian kemitraan masyarakat adalah kegiatan mendongeng. Dongeng yang dilakukan adalah dongeng nusantara dengan mengadopsi cerita yang berisi edukasi untuk anak, seperti cerita malin kundang, ande-ande lumut dan cerita si kancil. Cerita yang berisi pembelajaran dan nasehat untuk anak kami tayangkan bergantian dan di setiap satu sesi penanyangan kami selingi dengan permainan dan hiburan serta pemberian doorprize bagi anak yang berhasil menjawab pertanyaan yang diajukan.
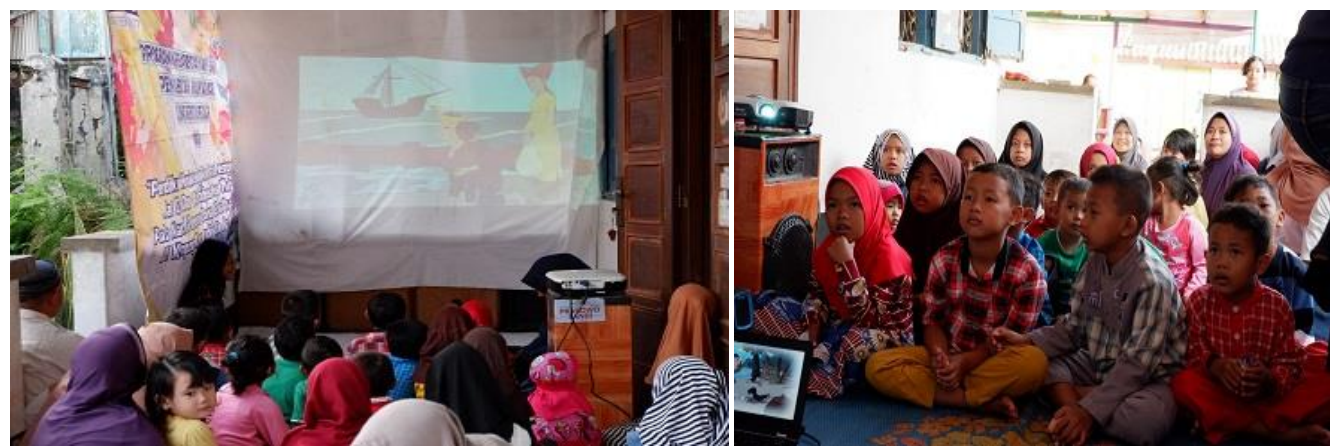

Gambar 2. Pemutaran Film Dongeng Anak Nusantara

Pada kegiatan dongeng nusantara ini, anak-anak di Kampung Karanggading diberikan pertanyaan ringan seperti contoh perbuatan sehari-hari mereka. Kemudian anak-anak diminta memperkenalkan diri mereka sekaligus menyebutkan cita-cita mereka setelah besar nanti.
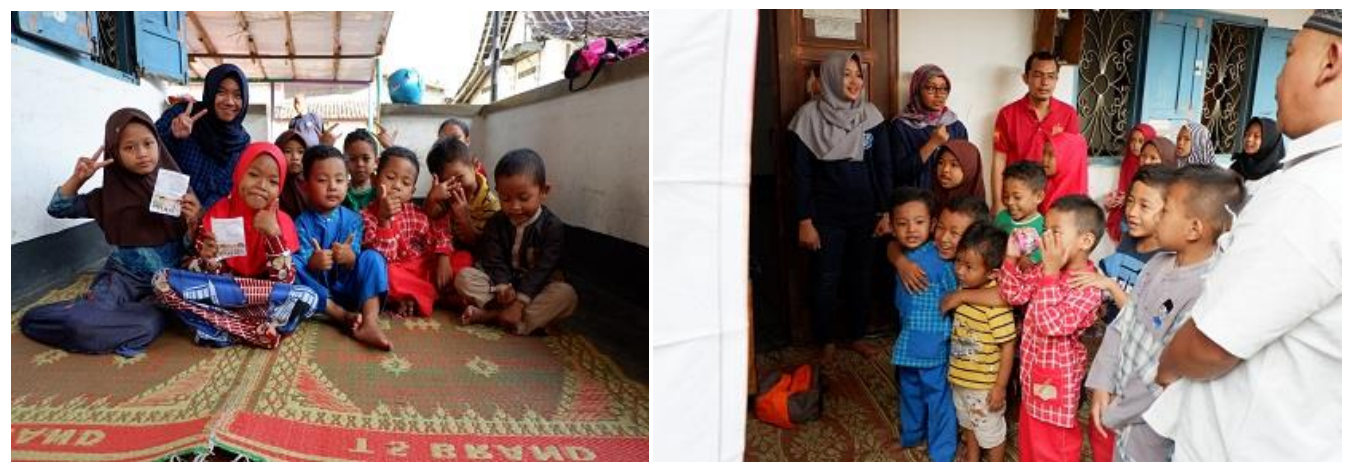

Gambar 3. Pemberian Pertanyaan dan Pembagian Doorprize

Tahapan selanjutnya adalah kegiatan untuk membangkitkan rasa nasionalisme anak-anak di Kampung Karanggading. Salah satu karakter atau elemen utama dalam nasionalisme adalah identitas sebagai sebuah bangsa. Nasionalisme tidak sama dengan patriotisme, yang lebih merupakan suatu pengkondisian sosial dan perilaku individual untuk mendukung keputusan tindakan sebuah negara. Penguatan nasionalisme harus dilakukan kepada setiap elemen bangsa karena sebenarnya merekalah aktor-aktor yang diharapkan melawan ancaman radikalisme secara langsung dalam kehidupan sosial Indonesia. Program kegiatan kami yang kedua adalah outbond dan bermain bersama anak-anak di Kampung Karanggading. 


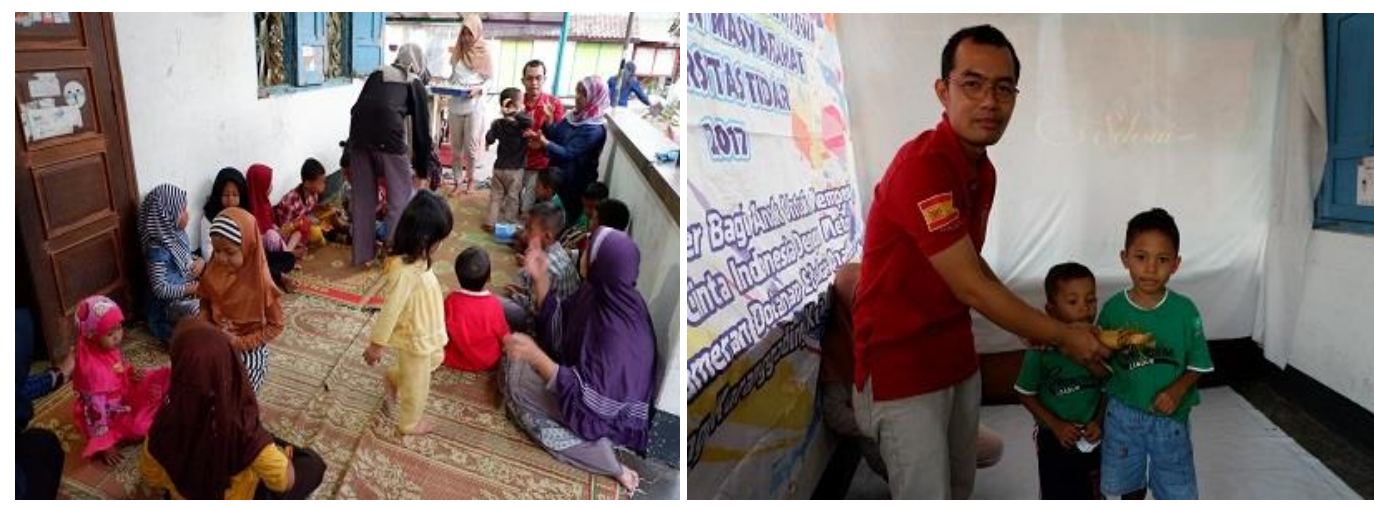

Gambar 4. Kegiatan Bermain Bersama Anak Kampung Karanggading

Pada kegiatan kedua ini kami berusaha membangun kekompakan anak dan juga kekompakan tim pelaksana pengabdian. Pemberian doorprize bagi anak memotivasi mereka untuk belajar berani dan jujur, yang merupakan modal dasar bagi mereka dalam menjalani kehidupan kelak.

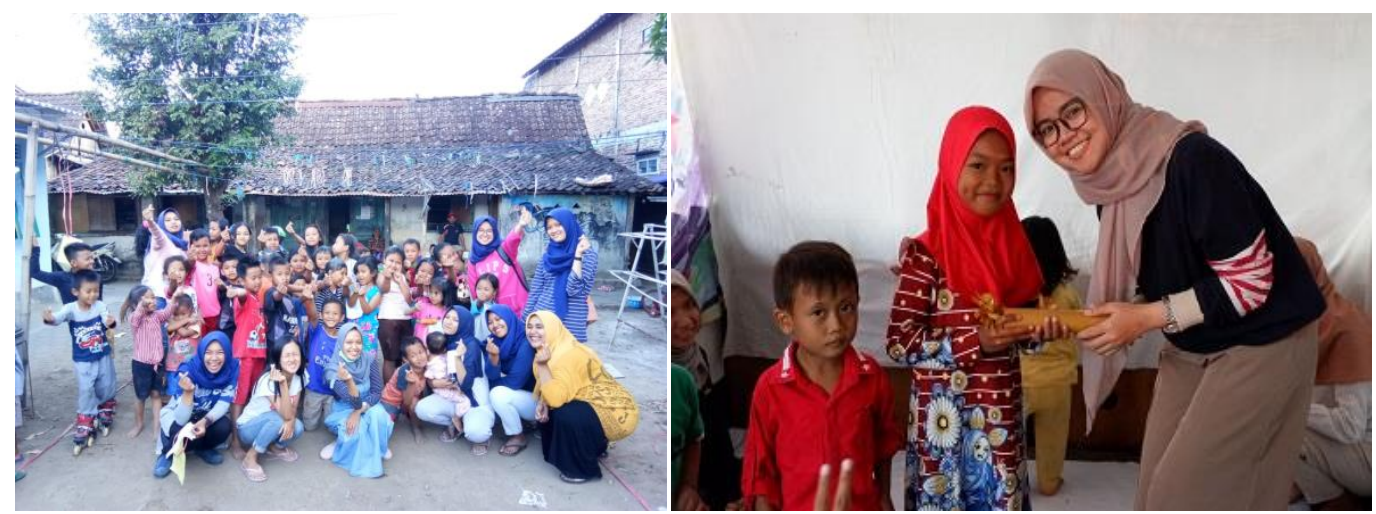

Gambar 5. Tim Pengabdian Masyarakat

Selanjutnya kegiatan ketiga yang kami lakukan adalah kerja bakti bersama anak dan warga masyarakat di Kampung Karanggading. Pertumbuhan organisasi teroris dapat dipicu dari kebiasaan budaya (cultural habit) yang menerima tindakan kekerasan atau radikalisme. Isu kultural yang dikaitkan dengan fenomena terorisme di Indonesia memperlihatkan mudahnya pengaruh ideologi radikal untuk masuk. Kegiatan gotong royong kerja bakti yang kami lakukan bermaksud untuk membiasakan warga hidup sehat dan salah satu upaya untuk mempererat persaudaran di antara mereka. 

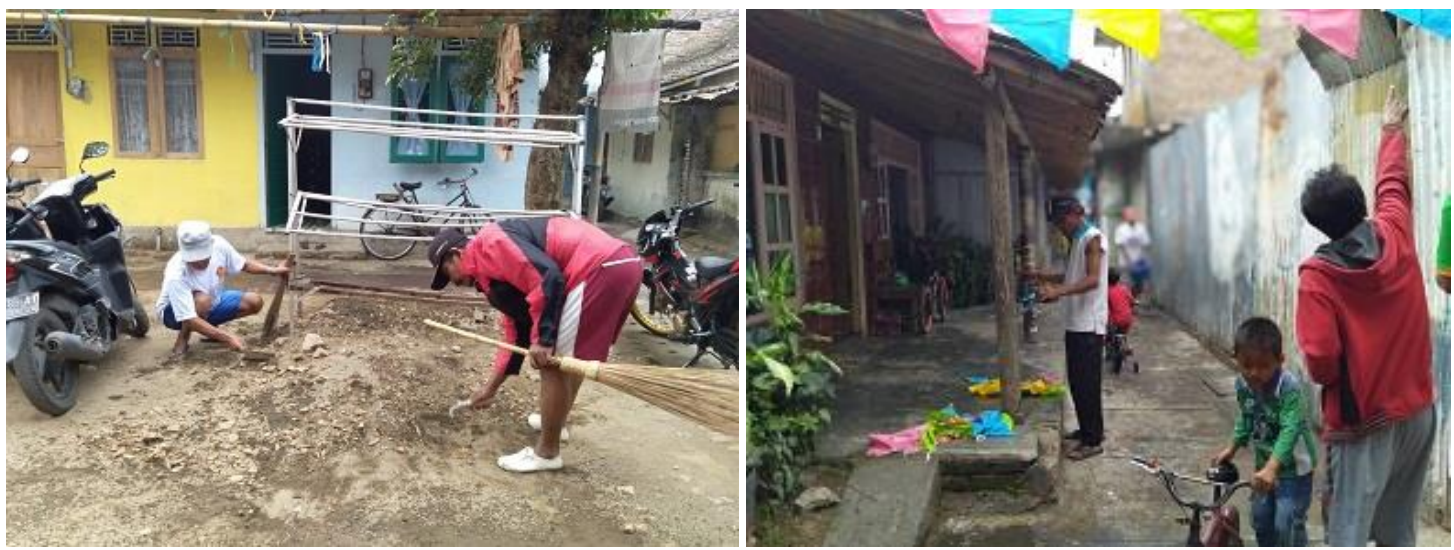

Gambar 5. Kerja Bakti Bersama Masyarakat Kampung Karanggading

Pelaksanaan pengabdian kemitraan masyarakat perlu ditindak lanjuti dengan melaksanakan kegiatan penguatan kelembagaan dan mengaktifkan kembali yang sudah ada di Kampung Karanggading seperti Karang Taruna dan PKK serta masyarakat yaitu:

1. Menghidupkan kembali organisasi kepemudaan (Karang Taruna) di Kampung Karanggading yang telah lama vakum.

2. Membantu organisasi kepemudaan (Karang Taruna) untuk membuat program kerja yang bermanfaat bagi lingkungan mereka.

3. Mengaktifkan kembali kader kesehatan lingkungan melalui revitalisasi kegiatan PKK.

4. Pembekalan digital sejak dini kepada anak-anak Kampung Karanggading agar dapat menggunakan media internet dengan lebih bijaksana.

\section{KESIMPULAN}

Dengan adanya kegiatan deradikalisasi pada anak usia dini diharapkan mampu menangkal paham radikalisme di Kampung Karanggading. Kegiatan dongeng nusantara, outbond dan kerjabakti menumbuhkan budaya anti kekerasan dan radikalisme. Radikalisme dan terorisme jarang terjadi pada lingkungan masyarakat yang tidak biasa menerima budaya kekerasan sebagai bagian dari tradisi mereka. Masyarakat Kampung Karanggading, khususnya anak-anak mendapatkan pemahaman mengenai nasionalisme dalam kehidupan mereka sehari-hari. Adapun tindaklanjut pengabdian selanjutnya kami akan bekerjasama dengan instansi terkait seperti Badan Kesatuan Bangsa Politik di Kota Magelang untuk membuat program deradikalisasi anak usia dini dengan lokasi pengabdian yang lebih luas.

\section{UCAPAN TERIMA KASIH}

Kegiatan Pengabdian Kepada Masyarakat melalui Program Deradikalisasi Anak Usia Dini Di Kampung Karanggading Kota Magelang dapat terselenggara dengan baik dan lancer berkat kerjasama berbagai pihak. Untuk itu bagi pihak-pihak terkait yang telah membantu menyukseskan kegiatan ini kami sampaikan terimakasih untuk LPPM-PMP Universitas Tidar yang telah mendukung penuh Pengabdian Kepada Masyarakat ini dan Terimakasih untuk masyarakat Kampung Karanggading, Kota Magelang yang telah berpartisipasi dalam kegiatan Pengabdian Kepada Masyarakat selama kegiatan berlangsung. 


\section{DAFTAR PUSTAKA}

Amar Salahuddin. (2015). PEncegahan Radikalisme Melalui Penanaman Nilai-Nilai Multikultural Novel-Novel Indonesia. Amar Salahuddin Universitas Dharmas Indonesia ( UNDHARI ) Jalan Lintas Sumatera Km . 18 Nagari Koto Padang Kecamatan Koto Baru Kabupaten Dharm. Prosiding Kongres Bahasa Indonesia, 1(1), 1-15.

Arif, S. (2014). Islam, Pancasila dan Deradikalisasi (Vol. 53, Issue 9). PT Alex Media Computindo. https://doi.org/10.1017/CBO9781107415324.004

Asrori, A. (2017). Radikalisme Di Indonesia: Antara Historisitas dan Antropisitas. Kalam, 9(2), 253. https://doi.org/10.24042/klm.v9i2.331

Dan Efriza, R. M. J. I. (2017). Bela Negara Sebagai Metode Pencegahan Ancaman Radikalisme Di Indonesia. Jurnal Pertahanan \& Bela Negara, 7(3), 1-17. https://doi.org/10.33172/jpbh.v7i3.226

Hikam, M. (2016).Deradikalisasi_Peran_Masyarakat_Sipil_In.pdf.

Jafar, T. F., Sudirman, A., \& Rifawan, A. (2019). Ketahanan Nasional Menghadapi Ancaman Lone Wolf Terrorism Di Jawa Barat. Jurnal Ketahanan Nasional, 25(1), 73. https://doi.org/10.22146/jkn.41244

Kiki, E. (2020). Pemberdayaan Masyarakat Menggali Potensi Lokal Desa. Moderat: Jurnal Ilmiah Ilmu Pemerintahan, 6(1).

Lusi, A. B. (2017). Mencapai Deradikalisasi Semesta dengan Pendekatan Smart Power. PAX HUMAN (Jurnal Humaniora Yayasan Bina Darma, IV-1, 105-110.

Maksum, M. (2017). Ancaman dan Strategi Penaggulangan Terorisme di Dunia Dan Indonesia.

Rahmadi, H. B. (2018). Relevansi Dan Aplikasi Doktrin Wawasan Nusantara Dalam Analisis Ancaman Kontemporer. Jurnal Kajian LEMHANAS RI, 33(3), 51-64.

Royani, M. (2013). Pendekatan Deradikalisasi Dan Peran Pemerintah Daerah Dalam Mendukung Program Pemolisian Masayarakat Guna Mencegah Pengaruh Terorisme Di Daerah. Jurnal NESTOR Magister Hukum.

saihu dan marsiti. (2019). Pendidikan Karakter Dalam Upaya Institut PTIQ Jakarta Sekolah Menengah Atas Negeri 3 Depok Abstrak. Pendidikan Islam, 1(1), 23-54.

Satriawan, I., Islami, M. N., \& Lailam, T. (2019). Pencegahan Gerakan Radikalisme melalui Penanaman Ideologi Pancasila dan Budaya Sadar Konstitusi Berbasis Komunitas. Jurnal Surya Masyarakat, 1(2), 99. https://doi.org/10.26714/jsm.1.2.2019.99-110

Sugiyono, prof. dr. (2010). Sugiyono Metode Penelitian Kuantitatif Kualitatif Dan R D DOWNLOAD. Sugiyono Metode Penelitian Kuantitatif Kualitatif Dan R D, 13-61.

Susilowati, E., \& Masruroh, N. N. (2018). Merawat Kebhinekaan Menjaga Keindonesiaan: Belajar Keberagaman dan Kebersatuan dari Masyarakat Pulau. Jurnal Sejarah Citra Lekha, 3(1), 13. https://doi.org/10.14710/jscl.v3i1.17856

Teguh, A. (2004). Kemitraan dan Model-Model Pemberdyaan. In Metrologia (Vol. 53, Issue 5). Gava Media. https://doi.org/10.1590/s1809-98232013000400007

Yudi Latif. (2018). Identitas Keindonesiaan dan Aktualisasi Pancasila bagi Generasi Milenial di Era Digital. Jurnal Kajian LEMHANAS RI, 33(3), 5-19. 